\title{
Regional and Multilateral Dimensions of the United States Balance of Payments*
}

\author{
Remarks by ANDREW F. BRIMMER, Member, \\ Board of Governors of the Federal Reserve System, \\ Before a Luncheon Sponsored Jointly By The Boards of Directors of the \\ Federal Reserve Bank of St. Louis and its Louisville Branch \\ Louisville, Kentucky, October 14, 1971
}

\begin{abstract}
A CONSIDERABLE number of words have been spoken and written about the United States balanceof-payments problem, and in the last two months vigorous steps have been taken to correct the deep and persistent deficit. However, both before and after the mid-August actions, explanations of the causes of our balance-of-payments difficulties have varied widely. And, as one would expect, these different explanations have led to a variety of conclusions as to the appropriate cure. Unfortunately, many of these suggested courses have involved the pursuit of partial and specific targets, rather than focusing more broadly on the multilateral dimensions of the problem. I believe we must look to these broader aspects if we are to achieve lasting improvement.
\end{abstract}

Among the more specific targets for action to reduce the deficit have been the following:

Military expenditures abroad: How can the level be reduced? How big a premium should be paid for procurement in the U.S.?

Private capital outfows: How much restraint should be imposed on purchases of foreign securities, on direct investment, and on U.S. bank lending abroad?

Unfair trading practices of foreign countries: What are the best ways to reduce barriers which discriminate against U.S. exports.

\footnotetext{
"I am indebted to several members of the Board's stafl for assistance in the preparation of these renarks, especially to Mr. Samuel Pizer, Miss Kathryn A. Morisse, and Mrs. Betty L. Barker.
}

Among the more generalized targets have been the following:

Inflation in the United States: How can excess demand be curbed to help check deterioration in our trade account?

Structural changes and foreign competition: How can we cope with modemization and productivity improvements abroad which enhance the ability of foreign countries to compete in merchandise trade with the United States?

Exchange rate adjustment: Can exchange rate adjustments be envisaged that would contribute significantly to improving the U.S. competitive position?

Cutting across these categories, the point is often made (usually in connection with an analysis of merchandise trade flows) that our increasing deficits can be traced to transactions with a few countries or regions. Usually Japan and Canada are singled out. It is then suggested that we should concentrate our efforts on improving our situation with those countries in particular.

Clearly we are dealing with a most complex - if not the most complex - problem in economic analysis and policy making. Much could be said about each of the factors or types of intemational transactions listed. Yet, a clear lesson to be learned from the collapse of the payments system this year is that there are many factors at work - each of which on the surface can be blamed for a large part of our deficits of the last few 
years. In fact, if we added up the separate effects of these different factors, we would quickly come to a sum that greatly exceeds our deficits. Furthermore, concentration on one aspect at a time tends to lead to policy prescriptions that are clearly inadequate. More importantly, we may be misled into the adoption of direct controls or other protectionist devices that can only hamper trade in the long run.

Given the complexity of our balance-of-payments diffculties, and in light of the current efforts to bring about a fundamental correction of the deficit, we should strive to increase our understanding of as many dimensions of the problem as we possibly can. One way of contributing to this understanding is to look in some depth at out transactions with various regions or countries and at the overall international trans actions of those regions. There are at least two reasons supporting such an approach. These relationships are intrinsically important, and there is a need to look at them more broadly than in terms of the trade accounts alone. There is also a need to recognize that adjustment of the U.S. balance of payments involves for each of these comntries or regions, not just a change in the bilateral relationship with the United States, but a many-sided adjustment involving their positions vis-à-vis the rest of the world as a whole.

With this objective in mind, and without attempting a detailed analysis of trends in U.S. trade and financial relations with major foreign countries and areas, a brief review has been made of the regional pattern of our trade and service transactions and of long-term private capital flows. The results of the analysis are presented in the following sections, but a summary can be sketched here:

The persistent deficit in our overall balance of payments (which reached an annual rate of some $\$ 20$ billion in the first six months of this year) was the result of a fundamental deterioration in our competitive position which showed no signs of being checked. At mid-year, the outlook was for a further worsening in 1972. Thus, a striking change in the intemational competitive environment was called for. The measures announced by the United States on August 15 were directed at that objective.

Among the major countries and regions of the world, there is naturally a primary interest in our trade and payments relations with those countries en joying sizable surpluses - particularly Canada, Japan, and Germany. In what follows, I will focus on trends in the current and long-term capital accounts so as to avoid the wide fluctuations in the flows of short-term capital.
With respect to Canada, a striking and lasting change has occurred in the United States-Canadian bilateral relationship since the early 1960 s. In 1970 , the over all U.S. deficit with Canada amounted to $\$ 1.7$ billion, compared with a surplus of $\$ 0.8$ billion in 1964 . Indeed, Canada's overall position in the world economy has improved dramatically, and a substantial share of the gain las centered in its trade with the United States. A significant part of this strengthening is a result of the United States-Canadian automobile agreement. In the quest to correct the deficit in the U.S. balaice of payments, it may be appropriate to remove the restrictions on exports of U.S. automobiles to Canada contained in the 1965 agreement.

In the case of Japan, the U.S. bilateral deficit amounted to $\$ 1.6$ billion last year; in 1964 the deficit was much smaller, under $\$ 100$ million. These growing deficits with Japan reflected spurts in U.S. imports. While voluntary quotas have moderated the rate of expansion in our deficit with Japan, the latter's restrictions on imports have hampered poten tial U.S. exports to an even greater degree. Conse. quently, a reduction of Japanese barriers to U.S. trade must be a principal objective of the current negotiations to rebuild the payments system.

The United States overall balance of payments with Western Europe registered a surplus of nearly $\$ 1$ billion in 1970 . In 1964, our accounts were in deficit by $\$ 160$ million. However, in the first six months of this year, we recorded a deficit of $\$ 1,6$ billion with Western Europe. Almost half of that total was with the European Economic Community (EEC). The noticeable deterioration in the U.S. balance of payments with Western Europe in the last year or so reflected the waning of favomable capital fows and the passing of the fortuitous benefits to our trade from cyclical developments here and abroad. More fundamentally, however, the greatly strengthened position of Western Europe can be traced to a basic change in its competitive stance vis-à-vis the United States.

Changes in the U.S. bilateral balance of payments with other countries have been far less dramatic. There was no significant change in our position with respect to other developed countries (Australia, New Zeakand, and South Africa) between 1964 and 1970 . In the case of developing nations, the major change in flows vis-à-vis the United States has been an increase in the amount of long-term private capital they have received $\ldots$ which rose from $\$ 1$ billion in 1964 to $\$ 1.6$ billion last year. U.S. trade with these areas has remained virtually static since the early $1960^{\circ} \mathrm{s}$, showing an annual U.S. surplus of about $\$ 1.5$ billion.

The bilateral balance of payments of the United States with other regions can show only a part of the overall payments situation which they face. Wo must look at their surplus or deficit position with the rest of the world if we are to evaluate the extent to which they could or should adjust their external transactions as part of their contribution to rebuild- 
ing the international payments system. Such a review shows that the major countries which have large surpluses with the United States (particularly Canada, Germany and Japan) also have overall surpluses with the rest of the world. However, taking all the leading industrial countries as a group, it is clear that they will have to withstand a sizable diminution in their aggregate surpluses if the United States is to make meaningful progress in correcting its own deficit.

\section{Regional Dimensions of the \\ U.S. Palance of Pauments}

The published data on the U.S. balance of payments enable one to trace our transactions with major foreign countries and areas. These data are summarized in Tables I and II. ${ }^{.}$Our overall balance on trade, serv" ices, and long-term private capital transactions (sometimes called the "basic" balance) has been nearly always in deficit since 1960 - and generally on a rising scale. By 1970 , this underlying deficit was $\$ 3$ billion and in the first half of 1971 , it reached $\$ 4.8$ billion (not an annual rate). This latest increase may have been exaggerated somewhat by the strikes then in effect or threatened and by changes in the timing of payments as traders and investors moved to protect themselves against the unstable international monetary situation. But the basic worsening was unmistakable, and projections for 1972 indicated that a further worsening was in store unless a striking change in the international competitive environment was brought about.

The worsening trend appeared in most major categories of transactions. Our trade balance moved into an almost unprecedented deficit position in April, and in the April-August period the United States ran a

${ }_{1}^{1}$ Note on Trade Data, Tables I, II, III, and IV.

Data in Table IV are reported on the same basis as in Table I and Table II (e.g., balance-of-payments basis - exports and imports f,o.b.).

The trade data reported in Table III differ from data in Tables I, II, and IV because:

1. Imports in Table III are derived from export data as reported by the partner exporting countries. For example, exports of the United States to Canada are also by definition, Canadian imports from the United States. These derived Canadian imports will differ from Canadian imports as reported in Canadian trade statistics.

2. Export data in Table III are adjusted by the United Nations to conform to U.N. standards.

3. Western Europe's trade balances with the United States, Canada, and Japan, as shown in Table III, appear to be consistent with those shown in other sources. However, Western Europe's trade balances with the rest of the world, as derived from the United Nations data, differ markedly from those shown in other sources, and these differences have not yet been reconciled. deficit at an annual rate of over $\$ 4$ billion. Private long-term capital registered a moderate net outflow of $\$ 1.5$ billion in 1970; but in the first six months of this year, the net outflow totaled $\$ 3.3$ billion. The net outflow associated with U.S. Government economic grants and capital flows also rose somewhat. The exception to this trend was a considerable rise in U.S. net re ceipts from service transactions, mainly because of an improvement in net income receipts. This rise was also to a considerable extent a temporary bulge related to some special transactions.

Having sketched in the overall trends in these major accounts, let us now tum to the trends in our dealings with some of the major regions of the world.

Canada: Between 1964 and 1970, our overall trade balance deteriorated by $\$ 4.7$ billion. Of this amount, $\$ 2.5$ billion was in trade with Canada. About $\$ 1.2$ billion of the change in the U.S. trade balance with Canada was in automobiles, trucks, and parts. How. ever, even apart from this special factor, U.S. trade with Canada worsened by over $\$ 1$ billion during the 1964-70 period. The further worsening in 1970 (apart from automobiles) resulted from a sizable increase in U.S. imports, while exports to Canada rose only slightly because of the weakness of the Canadian economy. In the first half of this year, the U.S. trade balance with Canada again declined substantially, as the deficit ran at an annual rate of nearly $\$ 2$ billion. One might have expected that reduced trade balances with Canada would have been offset by increases in other current account transactions, especially net investment income. Yet, net receipts from these transactions have grown very slowly and have been only a minor offset to the losses on trade account.

The flow of private long-term capital to Canada has been relatively free from restraints, but the volume has shown no tendency to rise since the middle-1960's. In fact, the outflow was relatively small in the first half of this year (roughly $\$ 230$ million). In considerable part, the slowdown in these flows reflects efforts by the Canadian Government to reduce the dependence of Canadian borrowers on the U.S. capital market.

Looking ahead, as the pace of economic activity picks up both in Canada and in the United States, our trade balance with Canada should improve. However, the net outflow of private capital will probably expand also. The rise in the exchange rate for the Canadian dollar should help the trade balance to become less unfavorable for the United States. Over the longer run, the bilateral trade balance may also 
Table 1

Regional Distribution of the U.S. Balance on Current Account and Long-Term Capital (millions of dollars)

\begin{tabular}{|c|c|c|c|c|c|c|c|c|}
\hline & & & & & & & 70 & 1971 \\
\hline & & & & & & $\begin{array}{l}\text { Ist } \\
\text { Half }\end{array}$ & $\begin{array}{l}\text { 2nd } \\
\text { Half }\end{array}$ & $\begin{array}{l}1 \mathrm{st} \\
\text { Half }\end{array}$ \\
\hline & 1960 & 1965 & 1968 & 1969 & 1970 & lnots & asonally ad & usted? \\
\hline All Areas: & & & & & & & & \\
\hline Current account and long-ferm capital & $-1,100$ & $-1,814$ & $-1,349$ & $-2,879$ & $-3,038$ & $-2,210$ & --829 & $-4,802$ \\
\hline Goods, services, and remittances & 3,498 & 6,102 & 1,321 & 745 & 2,182 & 1,838 & 345 & 968 \\
\hline of which: Trade & 4,906 & 4,942 & 624 & 660 & 2,110 & 1,662 & 448 & -418 \\
\hline Private long-ferm capital & $-2,100$ & $-4,577$ & 1,198 & -50 & $-1,454$ & $-1,956$ & 502 & $-3,284$ \\
\hline U.S. Govt. grants and capitall & $-2,553$ & $-3,340$ & $-3,869$ & $-3,574$ & $-3,766$ & $-2,092$ & $-1,675$ & $-2,488$ \\
\hline Canada: & & & & & & & & \\
\hline Current account and long-term capital & 686 & 320 & -512 & $-1,367$ & $-1,651$ & -402 & $-1,247$ & -333 \\
\hline Goods, services, and remittances & 1,311 & 1,712 & 433 & 47 & -596 & 116 & -712 & -79 \\
\hline of which: Trade & 1,024 & 864 & -435 & -799 & $-1,676$ & -581 & $-1,095$ & -838 \\
\hline Private long-term capital & -623 & $-1,398$ & -963 & $-1,417$ & $-1,035$ & -522 & -513 & -231 \\
\hline U.S. Govt. grants and capital1. & -2 & 7 & 19 & 3 & -20 & 4 & -22 & -25 \\
\hline Japan: & & & & & & & & \\
\hline Current account and long-term capital & -131 & -466 & $-1,227$ & $-2,129$ & $-1,577$ & -683 & -895 & $-1,921$ \\
\hline Goods, services, and remittances & -98 & -479 & $-1,374$ & $-1,774$ & $-1,545$ & -583 & -961 & $-1,433$ \\
\hline of which: Trade & 225 & -387 & $-1,110$ & $-1,390$ & $-1,246$ & -442 & -804 & $-1,382$ \\
\hline Private long-term capital & -24 & -49 & 50 & -383 & -92 & -133 & 41 & -454 \\
\hline U.S. Govt. grants and capital 1 & -9 & 62 & 97 & 28 & 60 & 33 & 25 & -31 \\
\hline EEC: & & & & & & & & \\
\hline Current account and long-term capital & 4 & 4 & 919 & 1,725 & 532 & 39 & 494 & -794 \\
\hline Goods, services, and remittances & & & -721 & -46 & 497 & 548 & -50 & -98 \\
\hline of which: Trade & & & 150 & 1.045 & 1,718 & 1,029 & 689 & 340 \\
\hline Private long-term capital & & & 1,527 & 1,709 & -111 & -549 & 438 & -591 \\
\hline U.S. Govt. grants and capitall & & & 113 & 62 & 146 & 40 & 106 & -101 \\
\hline Other Western Europe: 2 & & & & & & & & \\
\hline Current account and long-term capital & -211 & -450 & 987 & -614 & 454 & -258 & 714 & 848 \\
\hline Goods, services, and remittances & 477 & 1,166 & -698 & $-1,012$ & -588 & -314 & -273 & -337 \\
\hline of which: Trade & 2,549 & 2,683 & 185 & 391 & 1,181 & 685 & 496 & 384 \\
\hline Private long-term capital & -752 & $-1,723$ & 1,991 & 634 & 1,146 & 171 & 976 & -436 \\
\hline U.s. Govt, grants and caplial' & 04 & 108 & -300 & -237 & -103 & -113 & 10 & -74 \\
\hline All Other: 3 & & & & & & & & \\
\hline Current account and long-term capital & $-1,499$ & $-1,218$ & $-1,516$ & -494 & -796 & -906 & 105 & -906 \\
\hline Goods, services, and remittances & 1,808 & 3,703 & 3,681 & 3,530 & 4,414 & 2,071 & 2,341 & 2,915 \\
\hline of which: Trade & 1,108 & 1.782 & 1,834 & 1,413 & 2,133 & 971 & 1,162 & 1,078 \\
\hline Private long-term capital & -701 & $-1,407$ & $-1,407$ & -593 & $-1,362$ & -923 & -440 & $-1,572$ \\
\hline U.S. Govt. grants and capital ${ }^{1}$ & $-2,606$ & $-3,517$ & $-3,792$ & $-3,430$ & $-3,847$ & $-2,054$ & $-1,794$ & $-2,257$ \\
\hline
\end{tabular}

Includes U.S. Government nonliquid liabilities to other than official reserve holders.

IIncludes the United Kingdom.

Includes international organizations, unallocated transactions, and certain long-term liabilities to private foreigners reported by banks not allocated by area.

AEEO countries are included in "Other Western Europe" prith to 1060

Note; Details may not add to totals because of rounding.

Source: U.S. Department of Commerce.

improve, despite the large U.S. demand for Canadianproduced materials of all kinds and the likelihood that Canada will strive for more self-sufficiency in manufacturing. Moreover, the United States faces con- tinued keen competition for the Canadian marke from Europe and Japan. Receipts from investments i: Canada should rise more strongly than in the pas as the Canadian economy recovers. The flow of U.S 


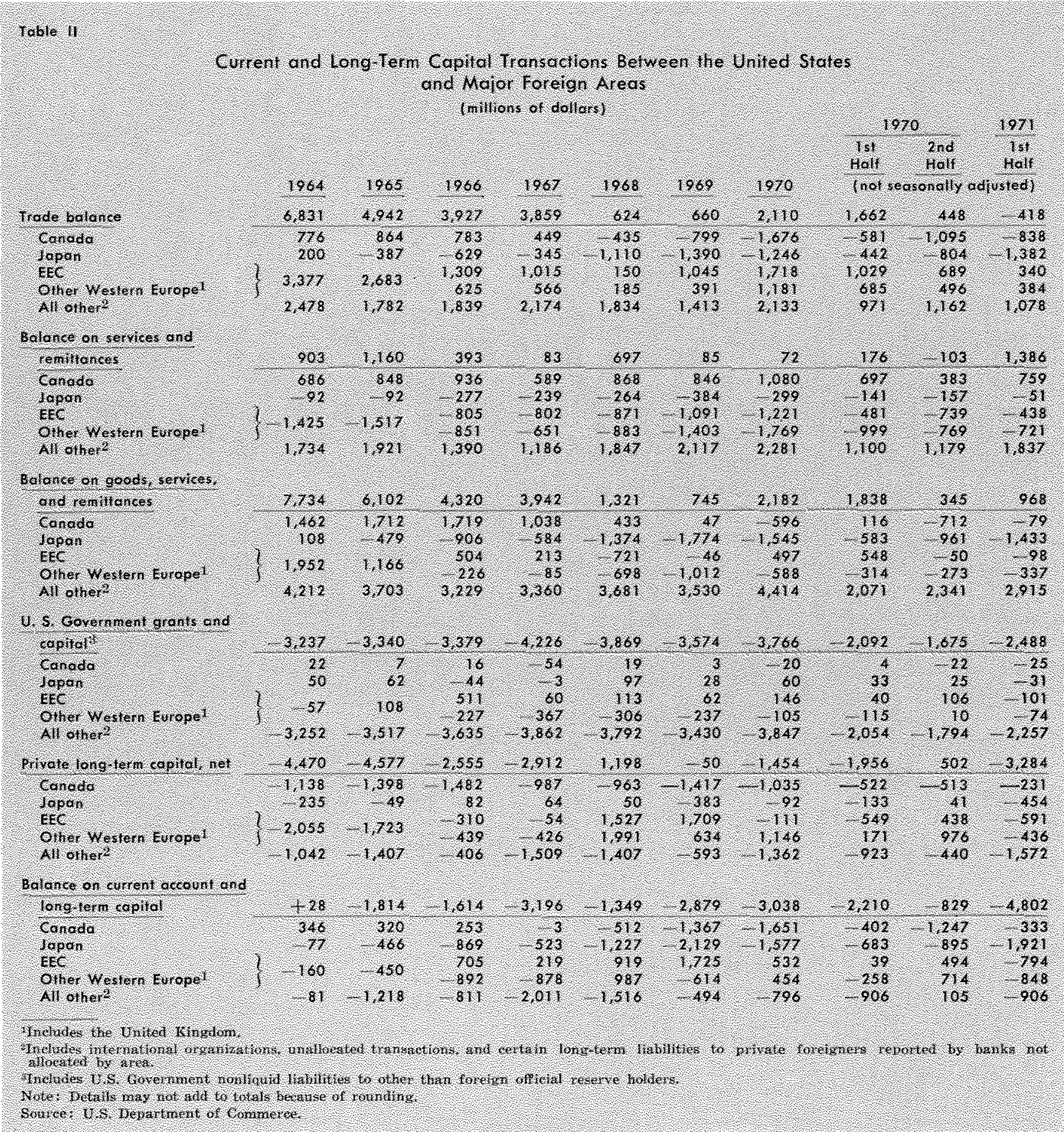

private capital to Canada may also trend upwards, but perhaps relatively slowly if Canadian capital markets become better adapted to Canada's needs.

Clearly a striking and perhaps lasting change has taken place in the United States-Canadian bilateral relationship since the early 1960's. Indeed, Canada's overall position in the world economy has changed dramatically, as noted in the following section, and much of the improvement has centered in its transactions with the United States.

Japan: In the case of Japan, the U.S. bilateral trade balance shifted into sizable deficit (\$387 million) in 1965 ; it moved to a still deeper deficit ( $\$ 1.1$ billion) in 1968, and then dropped sharply to a deficit at an 
annual rate of perhaps $\$ 2.8$ billion in the first half of 1971. These growing deficits reflected spurts in U.S. imports. Voluntary quotas imposed by Japan have kept the trade deficit from growing even faster. On the other hand, Japan's restrictions on imports have reduced potential U.S. exports, perhaps by an even larger amount.

The United States also has a deficit with Japan in the non-trade sectors of the current account, mainly direct military expenditures. This deficit also has risen over the period from about $\$ 100$ million in 1964 to about $\$ 300$ million in 1970 . Moreover, there has been a rising private long-term capital outflow to Japan, which would probably be substantially larger if restrictions were not imposed by both countries. These outflows rose sharply to nearly $\$ 0.5$ billion in the first half of this year, probably reflecting expectations of a Japanese revaluation. In 1970 , Japan's overall surplus on current and long-term capital transactions with the United States was about $\$ 1.6$ billion, compared to a surplus less than one-third as large in 1965. In the first half of 1971, these transactions resulted in a U.S. deficit of nearly $\$ 2$ billion with Japan. Although this total was inflated by anticipatory transactions of various kinds, the underlying trend was clearly and sharply adverse to the United States.

Western Europe: After averaging deficits of about $\$ 350$ million annually in 1964-67, the U.S. balance with Europe on current account and long-term capital was transformed into a surplus of $\$ 2$ billion in 1968 . The shift was due mainly to the impact of the tightening of U.S. controls on private capital outflows. After that, however, the surpluses diminished, and in the first six months of this year, we registered a deficit of $\$ 1.6$ billion in these transactions with Western Europe.

On trade account alone, the surplus with Western Europe dipped very sharply from 1964 through 1968. Subsequently it recovered markedly as the rise in U.S. imports slowed down while strong demand in Europe supported a steep rise in U.S. exports to those countries. The cyclical situation as between the United States and major European countries was especially favorable for the U.S. trade balance in 1970 , raising the surplus to $\$ 2.9$ billion - not far from the peak of 1964. However, over the coming year, as the United States moves toward more vigorous growth, at a time when output in the European countries will probably be lagging, some reduction in the trade balance is to be expected. Already in the first half of this year, the U.S. surplus in trade with Europe was only about $\$ 1.25$ billion at an annual rate.
The picture of U.S. transactions with Europe is significantly different when the whole current account is taken into consideration. On this basis, the U.S. position is noticeably weaker. The balance deteriorated by nearly $\$ 2$ billion between 1964 and 1970 . Of this amount, $\$ 0.5$ billion was in merchandise trade, and almost $\$ 1.5$ billion related to current transactions other than trade with Europe. Principal among these were larger deficits in tourism, rising military expenditures, and reduced net receipts on investment income (especially in 1969 and 1970) due to larger interest payments from the United States on accumulating debt.

More than offsetting the worsening of current transactions with Europe from 1964 to 1970 was the sharp improvement in the private long-tem capital accounts. These long-term capital flows shifted from a net outHow to Europe of about $\$ 2.1$ billion in 1964 to a net outllow of only $\$ 0.7$ billion in 1966 (after voluntary restraints on capital outflows were installed) and to a net inflow of about $\$ 3.5$ billion in 1968 (when man datory controls on certain capital flows were initiated). After that the net inflow of capital from Europe diminished, although it still remained at about $\$ 1$ billion in 1970. This year private long-term capital has again been flowing to Europe from the United States on an enormous scale, despite the restrictions.

The principal feature of the change in capital flows between the United States and Europe during the 1964-70 period was the dramatic increase in European investments in U.S. corporate securities and other obligations. This trend began in 1965, when the United States started a voluntary program to reduce the outflow of U.S. funds for direct investments abroad. The appeal induced U.S. corporations to seek financing in Europe, although the amounts involved were relatively small until 1968. In that year, the inflow of private capital from Europe (apart from short-term funds) rose to $\$ 4.5$ billion, from less than $\$ 1.5$ billion in 1967. The improvement reflected the combined impact of a tightening of the direct investment controls and stepped-up European purchases of U.S. stocks in a rising market. However, the inflow has slackened since then to about $\$ 3.5$ billion in 1970 and to less than $\$ 1$ billion in the first half of 1971 .

At the moment, the outlook for capital inflows from Europe is clouded by many uncertainties, not least of which is the anticipation of exchange rate changes. European purchases of U.S corporate stocks have dwindled. In any case, after the major portfolio adjustment that occurred in 1968-69 (with the help of vigorous marketing efforts by investment funds) the 
"normal" level of inflows could be expected to be considerably smaller. U.S. corporations have found it more difficult to sell long-term debt abroad and instead have turned to shorter-term financing for their foreign affiliates. European direct investments in the United States had been rising until recently, and they probably will do so again once the international financial environment has settled.

Flows of U.S. private long-term capital to Europe have been held down by the controls. The steep increase in plant and equipment expenditures of European affiliates of U.S. companies (from $\$ 2$ billion in 1968 to a projected $\$ 4.4$ billion next year) has been largely financed from foreign sources. Banks have reduced their credits to Europe under the Voluntary Foreign Credit Restraint Program, and the growth of the European bond market has relieved demands on U.S. capital markets - not only from European borrowers but also from Canadians and others.

To sum up this brief review, the improvement in the U.S. bilateral balance with Europe in 1970 depended mainly on a favorable shift in capital flows that at mid-year was already showing signs of diminishing and on an enlarged trade surplus that reflected in large part a favorable cyclical situation. Even though temporary factors may have contributed a good deal to the abrupt worsening in these trade and capital transactions with Europe so far this year, the underlying trend was clearly adverse.

Other countries: United States bilateral balances with other developed countries (Australia, New Zealand, and South Africa) did not shift significantly between 1964 and 1970. As for the developing countries, the principal change in flows vis-à-vis the U.S. has been an increase in the outflow of private capital to them in the last few years. The U.S. trade balance with developing nations has been nearly static since the early 1960's, showing an annual U.S. surplus of about $\$ 1.5$ billion.

\section{Oevall Position of Matow Regions}

The preceding review of the bilateral position of the United States with various regions, in terms of the balance on current account and long-term flows of private capital, can show only a part of the overall payments situation facing each of these regions. It is only by looking at their overall surpluses or deficits that we can evaluate the extent to which they could or should adjust their external transactions. In effect, the U.S. disequilibrium is the sum of the global disequilibria of other countries. So, when we speak of the adjustment that is needed from the U.S. point of view, we are really speaking about some sizable fraction of, say, the overall German surplus, rather than being concerned only with the German position vis-à-vis the United States.

The most accessible body of data on country-bycountry transactions relates to international trade. But it has not been possible to develop an accurate set of regional flows because of discrepancies in country statistics. A matrix of regional trade flows has been constructed as a starting point for discussion (Table III). However, it can only be used to indicate tendencies over the period and is less accurate for any given country than the data given in Table IV. Based on the United Nations data used in the matrix, the Canadian trade balance improved from a bare surplus of $\$ 0.3$ billion in 1965 to $\$ 3.7$ billion in 1970 . Of this $\$ 3.4$ billion improvement, $\$ 2.7$ billion came through trade with the United States. Canada's trade balance with Europe also improved substantially (by about $\$ 600$ million), and Canada even recorded an improvement in trade with Japan. Evidently, the Canadian gain was broadly based, although the brunt of the improvement fell on the United States.

Japan's trade balance rose about $\$ 2$ billion between 1965 and 1970. About half of the 1965-70 gain in trade was with the United States, a little over 35 per cent with Western Europe, and another 15 per cent with other countries. Of particular interest in the case of Japan is the sharp upsurge in the export surplus since mid-1970. In the last half of 1970, Japanese net exports jumped to an anmual rate of over $\$ 5$ billion, and the rate reached $\$ 5.7$ billion in the first half of 1971 (Table IV). Although trade with the United States accounted for about 40 per cent of Japan's overall trade surplus in 1970 , a larger share of the gain in 1971 seems to be in trade with this country. However, there have been several factors operating recently to bring about a temporary surge in Japan's balance with us. American and Japanese traders were probably attempting to anticipate strikes in the United States and to avoid being caught in a yen revaluation, while at the same time the Japanese economy has been going through a period of slowdown at home.

Although the U.N. data show a large overall trade deficit for Western Europe as a whole, country data suggest that (apart from a deficit with the United States) Europe probably has a surplus with the rest of the world. The trade positions of the individual European countries vary widely. These country balances have been assembled in Table IV. Among European countries, Germany has by far the strongest 
Tablo m

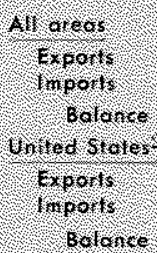

Connata

Export

tmport:

Belance

brat

Export:

inports.

B. olonce

Westin Europ:

Exo. 0 tr

$1,100 \times 15$

18010100

Best or ihe work

Expoits

inpor:

Betcinee

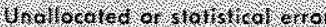

Cxporis

Impons

Bolante:

\section{A11 oreos: \\ Expoits \\ $1,398+1$ \\ Bolonte \\ United stotes: \\ Expoits \\ Impols: \\ Notionse}

Conoco

Expofts:

itrport

Balone.

Jopon

Exporits

Itipoets

Bolonece

Wosten twope

Exports

Inpors:

Bolonco

Rest of the Warlo

Exports

Inport:

Boldinte:

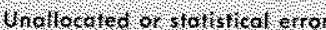

Exports

Bobonc

Regronal Trade Bolanaes of Major Wordd Areas, 1965 and 1970

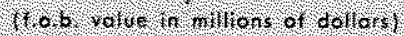

1065

fil.
areos

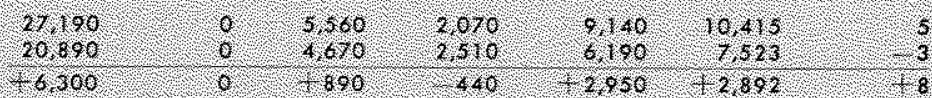

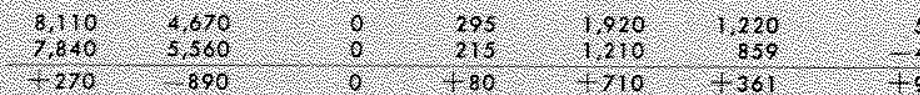

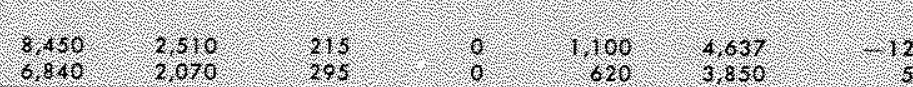

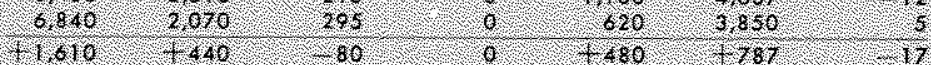

\begin{tabular}{|c|c|c|c|c|c|c|}
\hline 80,500 & 6190 & $1,1,10$ & 1,700 & 50,840 & 37,500 & 170 \\
\hline $\begin{array}{l}4 \% 30 \\
63 \% 10\end{array}$ & 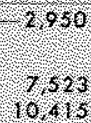 & 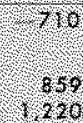 & $\begin{array}{l}460 \\
0.80 \\
4,37\end{array}$ & $\begin{array}{l}0 \\
\\
1,6,800 \\
10,800\end{array}$ & $\begin{array}{l}0,70 \\
89,16 \\
20,115\end{array}$ & 3 \\
\hline$\sqrt{1}, 40$ & 2,802 & 6 & $14 \%$ & (2) 135 & 0 & 4 \\
\hline
\end{tabular}

\begin{tabular}{l}
\hline \\
\hline
\end{tabular}

1970

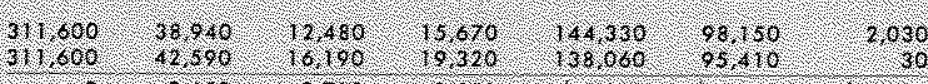

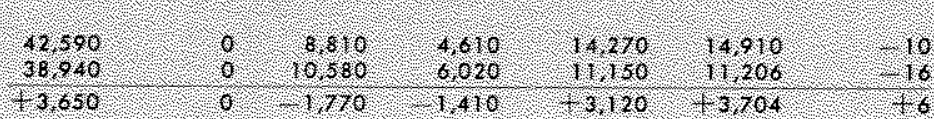

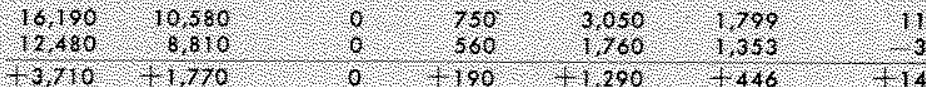

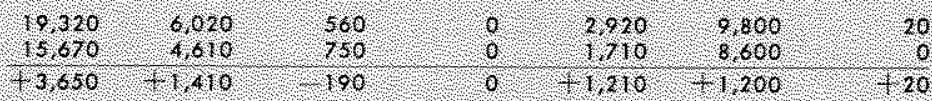

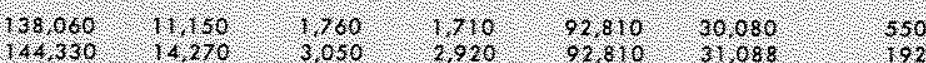

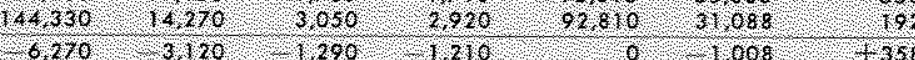

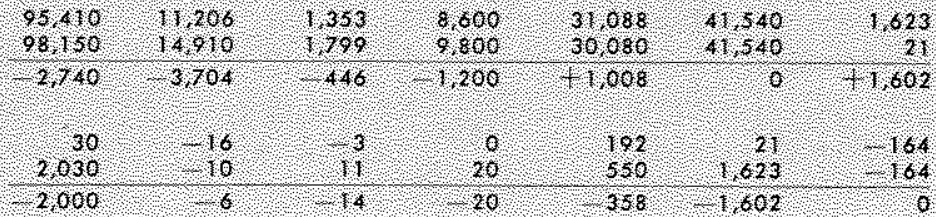

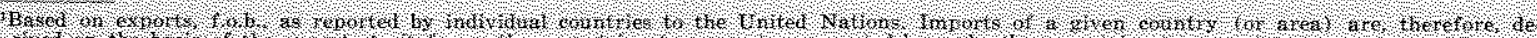

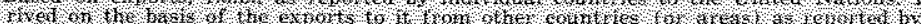

If

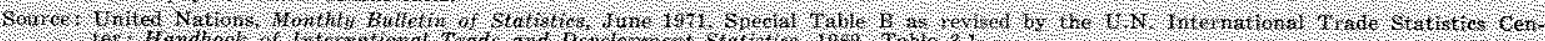
W. $10010 \%$ \% 


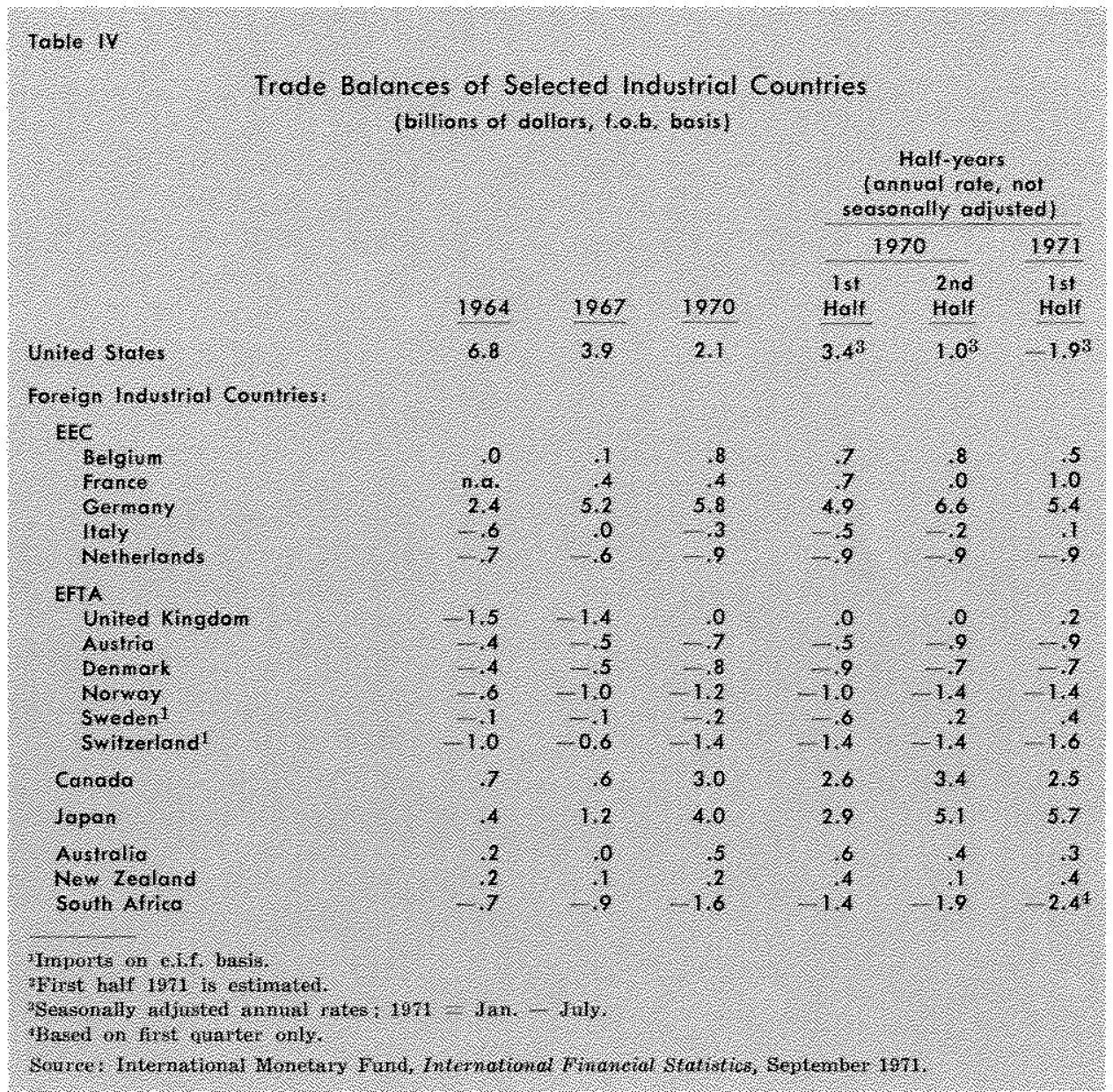

Italy, and Switzerland. In fact, for all the European countries (other than Germany) shown in Tables IV and $V$, net current receipts for non-trade transactions were approximately $\$ 8$ billion in 1970. Receipts from the United States ( $\$ 3$ billion) constituted a substantial part of the total (Table II).

\section{Trends in Reserves of Industrial Countries}

Up to this point, we have not been considering the effects of the massive flows of short-term capital which have so greatly aggravated the basic imbalances in world payments. These flows often escape the accounting mechanisms that have been developed to record capital flows. Consequently, we learn that they have occurred mainly because official reserves are changing in excess of the amounts that can be ac- trade position, with the other countries normally in deficit. Recently, however, several other countries (Belgium, France, the Netherlands, and the United Kingdom) have been improving their trade situation.

While these data on trade balances are informative, they can also be misleading as indicators of a country's overall surplus or deficit. For some countries, there are significant current account transactions apart from the trade accounts. For instance, statistics on current account balances in Table $V$ show that much of Germany's large trade surplus is offset by other current payments to foreigners - especially wages to foreign workers in Germany, tourist expenditures, and private remittances. Thus, although Germany had a trade surplus of $\$ 5.8$ billion in 1970 , that country's current account surplus was only $\$ 1.7$ billion. For Japan also, a large part of the trade surplus is offset by net payments on other current transactions. On the other hand, nearly all European countries except Germany derive substantial net receipts from current transactions apart from trade - with tourist receipts often a major source of income. These other receipts are especially important for the United Kingdom, Austria,

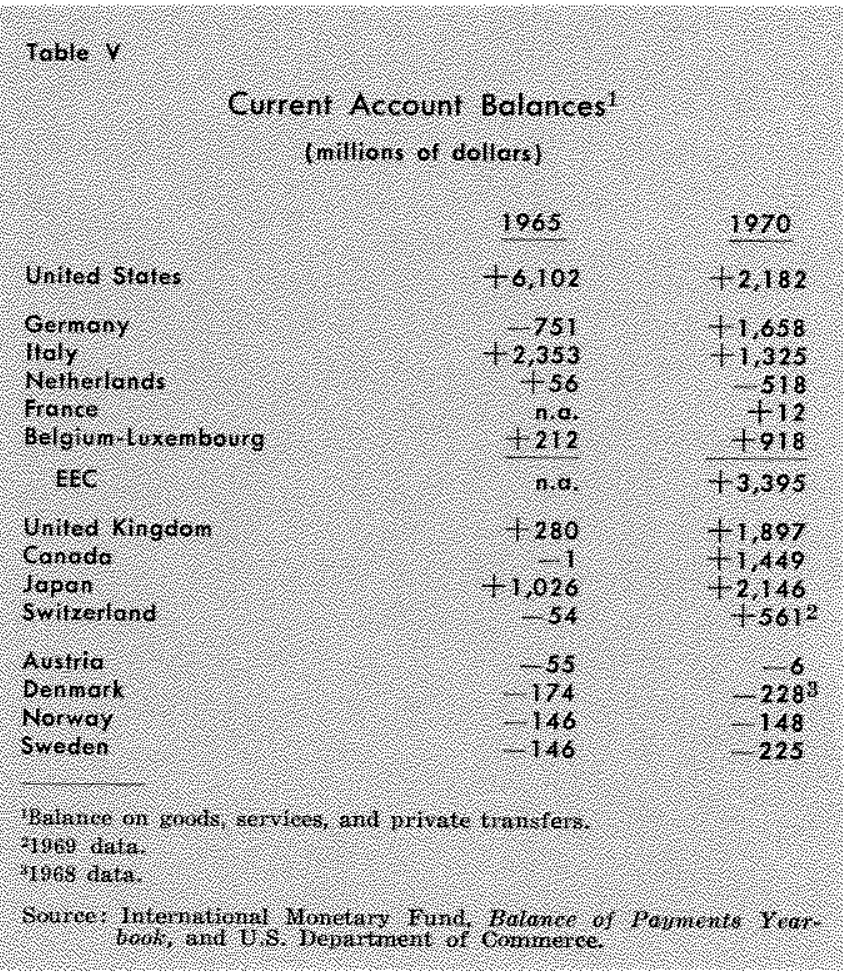




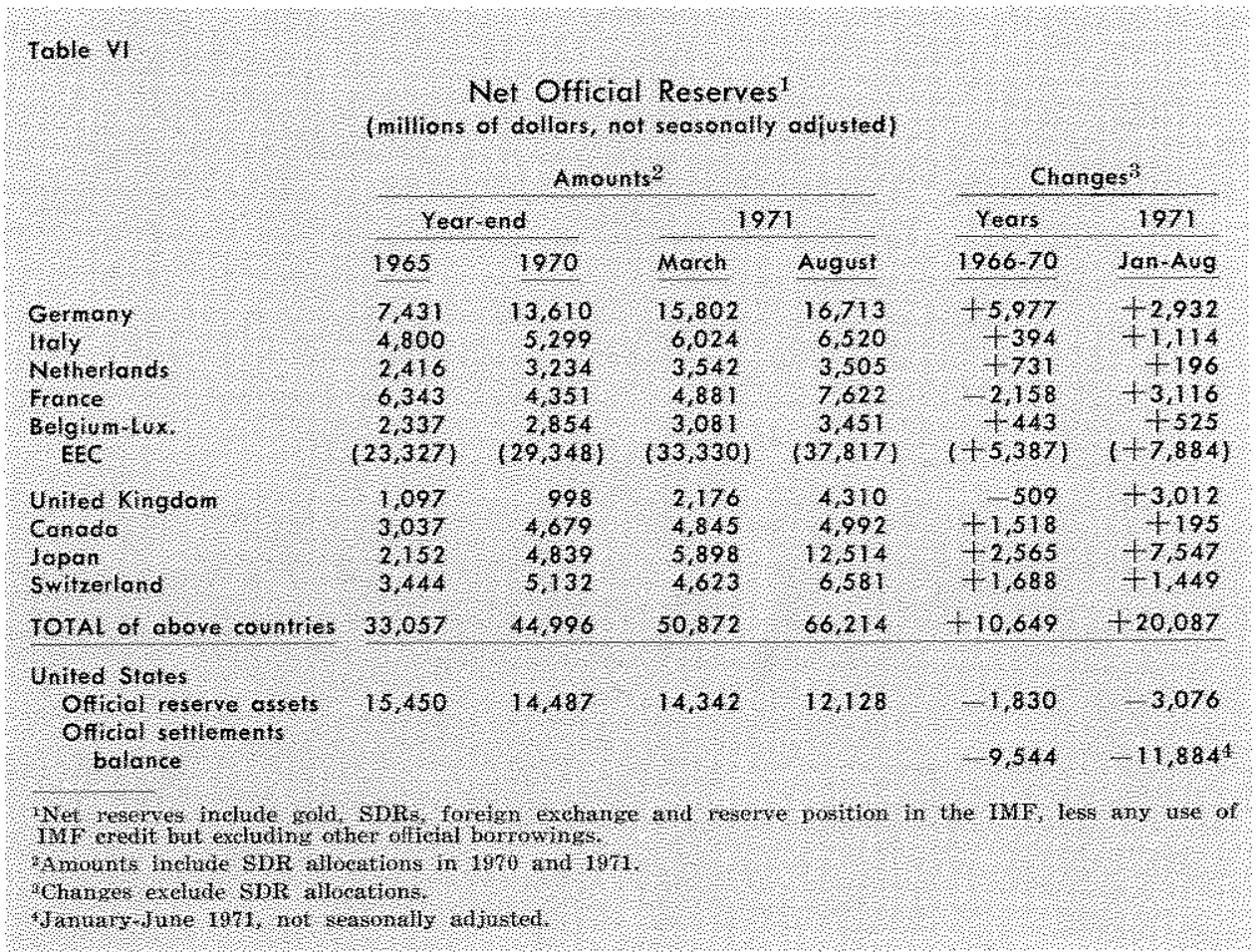

creased their reserves considerably. Although the U.S. deficit on official transactions was quite large, U.S. reserve losses were held down to under $\$ 2$ billion. The U.S. deficits were financed largely by borrowing.

In 1971, of course, there has been an enormous increase in reserves of foreign countries - a rise of about $\$ 20$ billion through August, and an additional but relatively minor gain has been registered since then. The published U.S. balance-ofpayments data cover only the first half of the year, when the official settlements deficit reached $\$ 12$ billion. However, from the figures showing changes in official re-

counted for by normal transactions. These flows may sometimes be outright flows of liquid funds from one currency to another, or they may take the form of shifting the timing of delivery or payment for ordinary commercial or financial transactions. Perhaps the best way to illustrate the size and direction, not only of these volatile capital flows but also the impact of the other trends we have been discussing, is to examine changes in countries' reserve positions.

As shown in Table VI, between 1965 and 1970, the net official reserves of the world's principal industrial countries (other than the United States) rose almost 40 per cent - from $\$ 33$ billion to $\$ 45$ billion. Some of this gain (about $\$ 1.3$ billion) represented allocations of Special Drawing Rights (SDRs). However, most of it was associated with the U.S. deficit on the official reserve transactions basis, which totaled $\$ 9.5$ billion for the period. Reserves of the countries constituting the European Economic Community (EEC) increased by over $\$ 5$ billion - apart from SDR allocations. Most of the expansion was concentrated in Gemany, which gained about $\$ 6$ billion. On the other hand, France was a major net loser of reserves ( $\$ 2.2$ billion) for that period as a whole.

Other major reserve gainers in the 1966-70 period were Canada ( $\$ 1.5$ billion), Japan ( $\$ 2.6$ billion), and Switzerland ( $\$ 1.7$ billion). In addition, some of the non-industrialized countries not discussed here in serves of leading foreign countries, it is evident that the U.S. deficits in the last few months were enormous.

Gains in reserves this year have been spread among many nations - most noticeably Germany, France, the United Kingdom and Japan. But other countries also had sizable increases relative to their total reserve holdings. By the end of August, net official reserves of these major countries had reached $\$ 66$ billion, compared to $\$ 12$ billion of reserves held by the United States. At the end of August, both Germany and Japan had larger reserves than the United States.

In my opinion, the size of these reserve gains is not really representative of the size of the U.S. imbalance. It will be recalled that a dominant feature of the three-month period prior to August 15 was a massive flow of liquid funds into those currencies that were thought to be the best candidates for appreciation. This flow included foreign funds previously held in dollar-denominated assets in the United States (mainly represented by borrowings by U.S. banks through their foreign branches) as well as outllows of U.S. funds either into foreign currencies or into high-yielding Eurodollar deposits. However, our discussion of the basic balance-of-payments position of the United States has shown that the situation was not merely a transitory crisis of confidence. Instead, the fundamental weakness in our trade and other transactions also had much to do with the deteriorating environment. The cumulative impact of these difficulties was 
too great to permit us to continue the pursuit of the same balance-of-payments policies.

\section{Enchange Pates and Millihateral Alusment}

Once the need for a change in policy was recognized, there could be no doubt that a large adjustment in the U.S. accounts was necessary. It was also clear that the adjustment would have to be distributed over a considerable number of countries. Part of the adjustment question involves specific actions to lessen discriminations against U.S. goods in world trade and a more equitable sharing of the burden of defense outlays.

More lastingly, however, there would have to be major changes in relative shares of world trade that could be brought about over time only by some adjustment in exchange rates. We could no longer see any reasonable possibility of effecting such changes through monetary and fiscal policies to control domestic inflation. There was simply too much lost ground to be regained.

From the United States' point of view, we are interested in a constellation of exchange rates that - along with other measures in the trade and burden-sharing areas - assures elimination of our deficit and provides a safety margin over time. A key to this outcome is a surplus on current account - which will have to center mainly in a surplus on trade account.

I am sure there will be agreement on at least one fact: no one can possibly estimate with any accuracy the effects on a particular country of the multiplicity of modifications in relative exchange rates and other features of the international monetary system that are currently at issue.
This very difficulty of seeing clearly what the effects of such changes will be in the months and years ahead is a strong argument, in my opinion, for allowing more flexibility of exchange rates than we have had during the last 25 years. Most of the key industrial countries seem to agree that some increased flexibility is a necessary feature of the new intemational monetary system that will emerge from the present negotiations. However, the crux of the issue turns on the extent to which those countries with sizable trade surpluses are prepared to see these balances shaved somewhat as part of the multilateral effort to make the payments mechanism function with a reasonable degree of predictability and efficiency.

In my personal opinion, as I have stated previously, the most urgent requirement at the present time is for a wider understanding among the major industrial nations with respect to the fundamental goals of the payments system, and for a better coordination of national goals in the areas of international trade, investment, and assistance to the developing countries. The efforts to negotiate new exchange rates and to promote institutional changes are obviously necessary. But I remain less than optimistic about the long-run viability of such arrangements unless there is a broad concensus on goals. The recent Annual Meeting of the International Monetary Fund did result in some movement in that direction, in that ten of its principal industrial members agreed on a list of priorities for negotiation and a plan of work over the months ahead. However, the tough issues of exchange rate adjustment and the reduction of trade barriers remain to be resolved. If we are successful in resolving these issues and also in producing fundamental improvements in the payments system, the benefits of increased international trade and investment would be considerable. 